\title{
Thoratec Centrimag VAD for cardiogenic shock - a developing country experience
}

\author{
M Villavicencio", V Rossel, R Larrea, J Peralta, E Larrain, J Lim, P Rojo, E Donoso, F Gajardo, M Hurtado \\ From 23rd World Congress of the World Society of Cardio-Thoracic Surgeons \\ Split, Croatia. 12-15 September 2013
}

\section{Background}

Circulatory support is usually not available in developing countries due to cost restrictions. Long-term devices are almost always not affordable for our health system and Thoratec Centrimag ${ }^{\circledR}$ may be an alternative. We report our experience in the treatment of cardiogenic shock with this intermediate-term device.

\section{Methods}

Thoratec Centrimag ${ }^{\circledR}$ was used in 22 cardiogenic shock patients. All were INTERMACS class I and all but one had multiorgan failure. Seventeen (77\%) were male, mean age $41+13$ years. Etiology was ischemic in $11(50 \%)$, dilated in $4(22 \%)$, and other etiology in $7(32 \%)$. Nine $(41 \%)$ had previous cardiac arrest with a mean arrest time of $18+16 \mathrm{~min}$. Circulatory support was biventricular in $18(82 \%)$, univentricular $4(18 \%)$, and in $6(27 \%)$ an oxygenator was interposed within the outflow line until respiratory recovery. Patients with veno-arterial ECMO configurations were excluded.

\section{Results}

Bridge-to-transplant or recovery was obtained in 14 out of 22 (64\%). Mean support time 44 days, range 1-292 days. Eight patients (36\%) were supported for more than 4 weeks. Thirty-day post-implant survival was $73 \%$ (16 patients). Post-implant complications were re-exploration for bleeding 7(32\%), neurologic dysfunction 3(14\%), pneumonia $8(36 \%)$, and renal failure with dialysis in (32\%). Eleven (50\%) patients are in NYHA class I after a mean follow-up time of $32+6$ months. Kaplan Meier one-year survival was $56+11 \%$. Eleven out of 12 (92\%) bridged-totransplant are in NYHA functional class I with normal biventricular function. One patient died 3 days post-

\footnotetext{
* Correspondence: villavicencio.mauricio@gmail.com

Cardiopulmonary Transplant Service, Instituto Nacional del Tórax, Santiago,
} Chile

(C) 2013 Villavicencio et al; licensee BioMed Central Ltd. This is an Open Access article distributed under the terms of the Creative Commons Attribution License (http://creativecommons.org/licenses/by/2.0), which permits unrestricted use, distribution, and reproduction in any medium, provided the original work is properly cited. transplant due to inflammatory response. Two patients were bridged-to-recovery. One is in NYHA class I and the other died due to non-compliance.

\section{Conclusion}

Thoratec Centrimag ${ }^{\circledR}$ is useful to provide intermediateterm circulatory support for cardiogenic shock and multiorgan failure in a developing country. Support time longer than 4 weeks is feasible. A multidisciplinary approach is needed since morbidity is common.

Published: 11 September 2013

doi:10.1186/1749-8090-8-S1-0156

Cite this article as: Villavicencio et al:: Thoratec Centrimag VAD for cardiogenic shock - a developing country experience. Journal of Cardiothoracic Surgery 2013 8(Suppl 1):0156.
Submit your next manuscript to BioMed Central and take full advantage of:

- Convenient online submission

- Thorough peer review

- No space constraints or color figure charges

- Immediate publication on acceptance

- Inclusion in PubMed, CAS, Scopus and Google Scholar

- Research which is freely available for redistribution Submit your manuscript at
www.biomedcentral.com/submit C BioMed Central

\section{Biomed Central}

